\title{
Liberalism and Value Pluralism
}

George Crowder

Continuum, London, 2002, $276 \mathrm{pp}$.

ISBN: 0-8264-5048-2/0-8264-5047-4.

Contemporary Political Theory (2004) 3, 122-124. doi:10.1057/palgrave.cpt.9300090

In 1994, George Crowder published an article in Political Studies in which he argued that there was no convincing case for justifying liberalism on the basis of value pluralism (Crowder, 1994). The article attracted a forceful rejoinder from Isaiah Berlin and Bernard Williams, to which Crowder himself later responded (Berlin and Williams, 1994; Crowder, 1996). Changing tack, Crowder now believes only that Berlin and others have not argued successfully from pluralism to liberalism, and this new book length treatment is his effort to make the case. The result is a busy, stimulating, readable book that makes some interesting suggestions, but leaves the most difficult questions untouched.

Plural values, Crowder maintains, are universal, incommensurable and conflicting - a characterization that is not controversial. More interesting is his attempt to draw substantive conclusions from the truth of pluralism: in particular, the possibility of rational choice between values. There are two ways this works. On a particularist view, attention to one's background conception of the good helps provide normative standards for decision. So (to use Crowder's example), as an academic I have more reason to go to the library than the beach even though both of these are worthwhile things to do. There is something to this contextualist approach, but it works more easily for individual choice than it does for states that have to enforce a common policy in the face of rival conceptions of the good. Hence we need a universal argument from pluralism to liberal norms too.

One such argument is famously offered by Berlin. Value pluralism, he maintained, gives us reason to champion choice over other values, and this in turn privileges liberalism. Crowder criticizes this on the grounds that choice itself is only one value among many in a pluralist universe. But, he claims, Berlin also has a second, implicit, argument: that pluralism implies an antiUtopian attitude to politics in which trade-offs and compromises have to be made, and that a liberal outlook best answers to this ineradicable feature of our political experience. This argument is more successful, but does not necessarily support liberalism since there are other outlooks also compatible with antiUtopianism. This leads Crowder to discuss John Gray's pragmatist and John Kekes's conservative philosophies. Kekes maintains that since pluralism rules out any compelling case for privileging any values over any others, we have no 
choice but to appeal to 'context' or 'tradition' in deciding what to do, and that conservatism best protects tradition. This seems a little odd: if values are plural then surely traditions are too? Crowder makes heavy weather of refuting Kekes, and is similarly charitable to Gray's political althought, although he ultimately claims that Gray ignores how pluralism can generate universal agreement on values.

Substantiating his claim that pluralism generates some universal norms is the task of the second half of the book. Here, Crowder offers three complementary arguments. First, acknowledging pluralism commits us to accepting an 'ethic of diversity' that endorses the variety of human values, and such an ethic is best achieved under liberal political arrangements. Second, and relatedly, acknowledging pluralism means we accept that there will forever be reasonable disagreement about values, and once again liberalism is the best way of managing and accommodating this disagreement. Third, pluralism supports liberalism as the best political vehicle for the development and practice of certain 'pluralist virtues' or traits of character. Practical reasoners in plural societies need to develop the virtues of broadmindedness, moderation, personal autonomy and so on, and these are all associated with liberalism.

The liberalism that all this supports is universal, moderately perfectionist, economically redistributivist and sympathetic to the rights of cultural minorities - provided they live within liberal limits. These last two features are surprising, because it is not clear whether reflection on pluralism alone really generates an egalitarian and multicultural type of liberalism, and Crowder's arguments that it does are not altogether convincing. Moreover, this descent into the foundations of public policy contrasts with the rest of the book which is, as Berlin and Williams $(1994,308)$ complained of Crowder's original article, pitched at an 'immensely abstract level'. Although, as Crowder points out, the writings of Berlin and Williams too show a penchant for abstraction, the question remains whether the relationship between liberalism and value pluralism is best addressed from this height or whether we do better to descend a level and examine particular disputes involving conflicting values on their own terms. Consider for example, the question of whether cultural minorities should receive state education in their own language. There are conflicting values we can appeal to here: assimilationism, diversity, tradition, cultural continuity. But the mere acknowledgement of such conflict will not help us. Or consider whether those on welfare should work for their benefits or receive an unconditional basic income from the state. How does a commitment to pluralism or liberalism help us here? In resolving such debates, Crowder says only that the multiple values must be balanced by 'coherence', but the latter is not developed as a criterion with any determinate policy implications. No doubt, Crowder would reply that his task is a more fundamental one: not to theorize about public policy, but to resolve the general second-order problem 
of whether pluralism supports a liberal outlook. I would suggest, however, that the latter is not an independent problem as such, but rather a generic label for a whole range of concrete issues facing liberal democacies in diverse societies. And I am not as convinced as Crowder is that we make progress on those issues through a general argument from pluralism to liberalism. For, whatever the form of that general argument, liberals have still to engage in the difficult business of developing more specific principles and conceptions, ones that make theoretical headway in accommodating people's competing intuitions. Crowder does make a good case for establishing the legitimacy of liberalism in a pluralist world. But since so many questions still confront us and, in any case, since most pluralists are liberals already, this can only be regarded as a preliminary task.

\section{References}

Berlin, I and Williams, B. (1994) 'Pluralism and Liberalism: a reply', Political Studies 42: 306-309. Crowder, C. (1996) 'Communication: Isaiah Berlin and Bernard Williams, "Pluralism and Liberalism"”, Political Studies 44: 649-650.

Crowder, C. (1994) 'Pluralism and Liberalism', Political Studies 42: 293-305.

Jonathan Seglow Royal Holloway, University of London. 